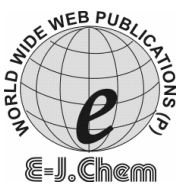

http://www.e-journals.net
ISSN: 0973-4945; CODEN ECJHAO

E-Journal of Chemistry

Vol. 5, No.3, pp. 620-626, July 2008

\title{
Synthesis, Physical Characterization and Biological Activity of Some Schiff Base Complexes
}

\author{
R.RAJAVEL ${ }^{*}$, M. SENTHIL VADIVU and C. ANITHA \\ Department of Chemistry, \\ Periyar University, Salem-636011, Tamilnadu - India \\ drrajavel@rediffmail.com
}

Received 21 December 2007; Accepted 23 February 2008

\begin{abstract}
Structural modification of organic molecule has considerable biological relevance. Further, coordination of a biomolecules to the metal ions significantly alters the effectiveness of the biomolecules. In view of the antimicrobial activity ligand [bis-(2-aminobenzaldehyde)] malonoyl dihydrazone], metal complexes with $\mathrm{Cu}(\mathrm{II}), \mathrm{Ni}(\mathrm{II}), \mathrm{Zn}$ (II) and oxovanadium(IV) have been synthesized and found to be potential antimicrobial agents. An attempt is also made to correlate the biological activities with geometry of the complexes. The complexes have been characterized by elemental analysis, molar conductance, spectra and cyclicvoltammetric measurements. The structural assessment of the complexes has been carried out based on electronic, infrared and molar conductivity values.
\end{abstract}

Keywords: Biological activity, 2-Aminobenzaldehyde, Malonoyldihydrazide, Oxovanadium(IV)

\section{Introduction}

Malonoyldihydrazide and 2-aminobenzaldehyde compounds are capable to form complexes with transition metal ions in the form Schiff bases. The complexes of copper(II), nickel(II), zinc(II) and oxovanadium(IV) have been prepared and investigated using different chemical techniques, such as; elemental analysis, molar conductance measurements, infrared, electronic spectra and cyclicvoltammetry. The obtained chemical analysis data showed the formation of $[\mathrm{M}: \mathrm{L}]$ ratio and a square planar geometry was suggested for copper(II), nickel(II) and tetrahedral geometry for zinc(II) complexes and a square pyramidal geometry for oxovanadium(IV) complex. Henri et $\mathrm{al}^{1}$ have synthesized two new Schiff bases derived form 2,3-diaminopyridine and $o$-vanillin and their transition metal complexes $(\mathrm{Cu}, \mathrm{Ni}, \mathrm{Fe}$, $\mathrm{Zn})$ and have characterized them by elemental analysis, magnetic susceptibility measurements, IR and NMR. The Schiff bases and most of their metal complexes are reported to have antibacterial activity. 
Rajavel and Krishnan ${ }^{2}$ have reported the synthesis and characterization of oxovanadium(IV) complexes of the Schiff bases derived by the condensation of 2aminobenzaldehyde with various diamines as 1,2-diaminoethane, 1,2-diaminopropane, 1,3diaminopropane and discussed the elemental analysis, electrochemical studies and spectral data of the complexes. Erdal canpolat $e t a l^{3}$ have reported the synthesis and characterization of a new 5-bromosalicylidene- $p$-aminoacetophenoneoxime and its complexes with $\mathrm{Co}$ (II), $\mathrm{Ni}(\mathrm{II}), \mathrm{Cu}(\mathrm{II})$ and $\mathrm{Zn}(\mathrm{II})$ Jian-ning Liu et al. ${ }^{4}$ have reported synthesis and characterization of metal complexes of $\mathrm{Cu}(\mathrm{II}), \mathrm{Ni}(\mathrm{II}), \mathrm{Zn}(\mathrm{II}), \mathrm{Co}(\mathrm{II}), \mathrm{Mn}(\mathrm{II})$ and $\mathrm{Cd}(\mathrm{II})$ with tetradentate Schiff bases. Nair et al. ${ }^{5}$ have reported synthesis and spectroscopic studies of complexes of $\mathrm{Cu}, \mathrm{Ni}$, $\mathrm{Fe}$ and $\mathrm{Zn}$. These complexes have been characterized by elemental analysis, electronic, IR and thermal studies.

The present paper aims to prepare, characterize the chemical structure and to study the antibacterial activity of the prepared Schiff base complex derived from malonyldihydrazide and 2-aminobenzaldehyde.

\section{Experimental}

All chemicals used in this work were reagent grade (AR/Aldrich), including $\mathrm{Cu}\left(\mathrm{ClO}_{4}\right)_{2} \cdot 6 \mathrm{H}_{2} \mathrm{O}, \mathrm{Ni}\left(\mathrm{ClO}_{4}\right)_{2} \cdot 6 \mathrm{H}_{2} \mathrm{O}, \mathrm{ZnSO}_{4}, \mathrm{VOSO}_{4}, \mathrm{DMSO}, \mathrm{DMF}$, TBAP, acetonitirile, malonoyldihydrazide, 2-aminobenzaldehyde and ethanol. Double distilled water was used.

\section{Synthesis of malonyldihydrazide}

Malonyldihydrazide was prepared by reacting the diethylmalonate (1mole) with hydrazine hydrate (2 moles)

\section{Synthesis of bis (2-aminobenzaldehyde) malonyldihydrazone}

The ligand was prepared by reacting a warm dilute ethanol solution of dihydrazide $(0.65 \mathrm{~g}$; 0.5 mole) with 2 -aminobenzaldehyde $\left(1.21 \mathrm{~g} ; 1\right.$ mole). The reaction mixture was refluxed ${ }^{6}$ for two hours and suction filtered, washed with ethanol and dried over desiccator. The melting point of the product was found to be $180^{\circ} \mathrm{C}$. The colour of the product was yellow (Yield 75\%) (Scheme 1).

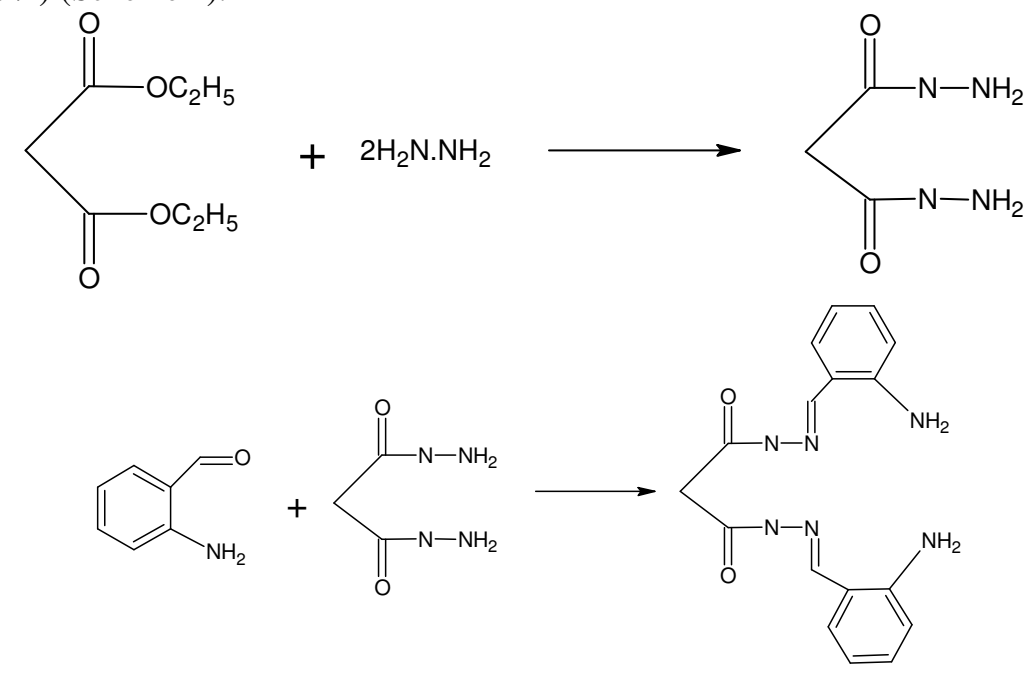

Scheme 1. 


\section{Synthesis of complexes}

The ligand was taken in ethanol and stirred gently for 30 minutes to give a homogeneous suspension. Thio was added to copper(II) perchlorate hexahydrate solution containing trace of acetic acid. The reaction mixture was refluxed for 3 hours. The dark blue product so obtained (Scheme 2) was filtered while hot, washed with ethanol and dried in a desiccator.

The other complexes were also precipitated by a similar procedure in ethanol medium.

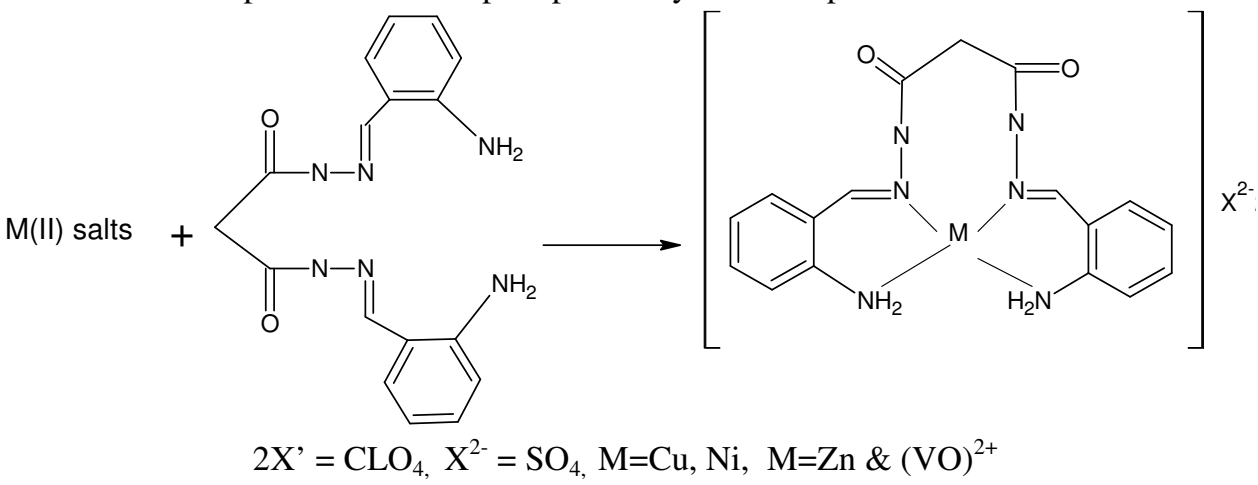

Scheme 2.

\section{Bacterial culture}

Different strains of bacteria E.Coli, P.aeruginosa, S.aureus and Bacillus subtilis (gram +ve) all strains were collected from clinical sample. The gram positive and gram negative bacteria were isolated from clinical sample and identified using physico-chemical methods. The identity of all the strains was confirmed. Antibiotic sensitivity test was studied by well diffusion method ${ }^{7}$. The bacterial suspension was prepared and added to well. The media with bacteria was poured into well under using suitable techniques. Different weights of the Schiff base and its complexes in DMSO solvent were placed on the surface of the culture and incubated at $37^{\circ} \mathrm{C}$ for one day. After incubation, the average of inhibition zones was recorded.

\section{Physico chemical measurements}

The elemental analysis for carbon, hydrogen and nitrogen were performed by microanalytical methods. IR spectra of the ligand and its complexes were carried out by using $\mathrm{KBr}$ disc IFS-25 DPUS/ IR spectrometer (Bruker) 1988Y. The electronic absorption was carried out by using a Perkin-Elmer Lambda $4 \beta$ spectrometer in $1 \mathrm{~cm}$-matched silica gel using $\mathrm{CHCl}_{3}$ as a solvent. The molar conductance measurements were carried out in DMSO using conductivity meter model CM Elico-185. CH instrument model 680 was used for recording the cyclic voltammogram of the complexes.

\section{Results and Discussion}

\section{Physico-chemical characterizations and geometrical configuration of the complexes}

Metal(II) salts react with Schiff base ligand in 1:1 molar ratio in alcoholic medium to afford dark green / blue complexes. The ligand and its complexes are stable at room temperature and are nonhygroscopic. The ligand is soluble in common polar organic solvents, such as ethanol, methanol, and chloroform but partially soluble in hexane. The Schiff base complexes are relatively well soluble in DMF and DMSO. The synthesized ligand and its 
complexes were characterized by elemental analysis, spectra, molar conductivity and electrochemical measurements. Apart from this, biological activity of the ligands and its complexes were studied. The geometry of the newly synthesized compounds has been elucidated based on their elemental analysis, molar conductivity and spectral data.

\section{Elemental Analysis}

The stoichiometry of the ligand and its complexes were confirmed by their elemental analysis. The metal / ligand ratio was found to be 1:1 has been arrived at by estimating the metal and nitrogen contents of the complexes. Elemental analysis of ligand and its $\mathrm{Cu}(\mathrm{II})$, $\mathrm{Ni}(\mathrm{II}), \mathrm{Zn}(\mathrm{II})$ and $\mathrm{VO}(\mathrm{IV})$ complexes show good agreement with the proposed structures of the ligand and its complexes Table 1.

Table 1. Analytical and physical data of the compound studied

\begin{tabular}{|c|c|c|c|c|c|c|c|}
\hline \multirow{2}{*}{ Compound } & \multirow{2}{*}{ Mol. Formula } & \multirow{2}{*}{$\begin{array}{c}\text { Mol. } \\
\text { Weight }\end{array}$} & \multirow{2}{*}{ Color } & \multicolumn{2}{|c|}{ Nitrogen, $\%$} & \multicolumn{2}{|c|}{ Metal, \% } \\
\hline & & & & Expt & Calcd & Expt & Calcd \\
\hline $\begin{array}{c}\text { Ligand } \\
\text { (ambmadh) }\end{array}$ & $\left(\mathrm{C}_{17} \mathrm{H}_{16} \mathrm{~N}_{6} \mathrm{O}_{2}\right)$ & 336.34 & Pale & 24.17 & 24.98 & - & - \\
\hline$\frac{\mathrm{Cu}(\operatorname{ambmadh})]}{\left(\mathrm{ClO}_{4}\right)_{2}}$ & $\begin{array}{c}{\left[\mathrm{Cu}\left(\mathrm{C}_{17} \mathrm{H}_{16} \mathrm{~N}_{6} \mathrm{O}_{2}\right)\right]} \\
\left(\mathrm{ClO}_{4}\right)_{2}\end{array}$ & 598.71 & $\begin{array}{l}\text { Dark } \\
\text { Blue }\end{array}$ & 13.92 & 14.03 & 10.42 & 10.61 \\
\hline $\begin{array}{l}{[\mathrm{Ni}(\mathrm{ambmadh})]} \\
\left(\mathrm{ClO}_{4}\right)_{2}\end{array}$ & $\begin{array}{c}{\left[\mathrm{Ni}\left(\mathrm{C}_{17} \mathrm{H}_{16} \mathrm{~N}_{6} \mathrm{O}_{2}\right)\right]} \\
\left(\mathrm{ClO}_{4}\right)_{2}\end{array}$ & 593.86 & & 14.01 & 14.15 & 9.71 & 9.88 \\
\hline $\begin{array}{c}\text { [Zn (ambmadh)] } \\
\mathrm{SO}_{4}\end{array}$ & $\begin{array}{c}{\left[\mathrm{Zn}\left(\mathrm{C}_{17} \mathrm{H}_{16} \mathrm{~N}_{6} \mathrm{O}_{2}\right)\right]} \\
\mathrm{SO}_{4}\end{array}$ & 497.77 & Brown & 16.41 & 16.88 & 13.01 & 13.13 \\
\hline $\begin{array}{c}{[\mathrm{VO}(\mathrm{ambmadh})]} \\
\mathrm{SO}_{4}\end{array}$ & $\begin{array}{c}{\left[\mathrm{VO}\left(\mathrm{C}_{17} \mathrm{H}_{16} \mathrm{~N}_{6} \mathrm{O}_{2}\right)\right]} \\
\mathrm{SO}_{4}\end{array}$ & 499.30 & $\begin{array}{l}\text { Dark } \\
\text { blue }\end{array}$ & 16.23 & 16.83 & 10.07 & 10.20 \\
\hline
\end{tabular}

\section{Molar conductance mesurements}

The molar conductance value $\left(40-50 \mathrm{ohm}^{-1} \mathrm{~cm}^{2} \mathrm{~mol}^{-1}\right)$ of the complex which was carried out in DMSO solvent indicates that the complex under study is $1: 1$ electrolytic nature ${ }^{8.9}$. Further, the low molar conductance of the complexes might arise due to large size of the anionic coordination sphere, which might have low ionic mobility. The values of molar conductance, suggest that complexes are electrolytes, there by showing that the perchlorate/sulphate ion is a counter ion.

\section{Infrared spectra}

The IR spectra provide valuable information regarding the nature of functional group attached to the metal atom. The ligand and metal complexes were characterized mainly using the azomethine and primary amine $\left(-\mathrm{NH}_{2}\right)$ bands. The main infrared bands and their assignments are listed in Table 2. The appearance of a broad strong band in the IR spectra of the ligand in $3400-3350 \mathrm{~cm}^{-1}$ is assigned to N-H stretching vibrations of the primary amine group. In the complexes, this band is shifted to lower frequency indicating that the ligand was coordinated to metal ions through the nitrogen atoms of the $\mathrm{NH}_{2}$ group ${ }^{10}$. The spectrum of the ligand shows two different $-\mathrm{C}=\mathrm{N}$ bands in the region $1590-1550 \mathrm{~cm}^{-1}$, which is shifted to lower frequencies in the spectra of all the complexes $\left(1570-1520 \mathrm{~cm}^{-1}\right)$ indicating the involvement of $-\mathrm{C}=\mathrm{N}$ nitrogen in coordination to the metal ion ${ }^{11,12}$. Assignment of the proposed coordination sites is further supported by the appearance of medium bands at 450$400 \mathrm{~cm}^{-1}$ which could be attributed to $v \mathrm{M}-\mathrm{N}$ respectively ${ }^{13,14}$. In addition, the Vanadyl complex shows a band at $940 \mathrm{~cm}^{-1}$ attributed to $\mathrm{V}=\mathrm{O}$ frequency ${ }^{15}$. 
Table 2. Characteristic IR bands $\left(\mathrm{cm}^{-1}\right)$ of the compounds studied

\begin{tabular}{ccccccc}
\hline Compound & $\mathrm{NH}_{2}$ & $\mathrm{C}=\mathrm{N}$ & $\mathrm{C}=\mathrm{O}$ & $\mathrm{V}=\mathrm{O}$ & $\begin{array}{c}\mathrm{ClO}_{4}^{-} \\
/ \mathrm{SO}_{4}^{2-}\end{array}$ & $\mathrm{M}-\mathrm{N}$ \\
\hline $\begin{array}{c}\text { Ligand } \\
\text { (ambmadh) }\end{array}$ & 3420 & 1640 & 1740 & - & - & - \\
{$[\mathrm{Cu}($ ambmadh $)]\left(\mathrm{ClO}_{4}\right)_{2}$} & 3380 & 1620 & 1723 & - & 1090 & 520 \\
{$[\mathrm{Ni}(\mathrm{ambmadh})]\left(\mathrm{ClO}_{4}\right)_{2}$} & 3350 & 1590 & 1732 & - & 1110 & 480 \\
{$[\mathrm{Zn}($ ambmadh $)] \mathrm{SO}_{4}$} & 3390 & 1600 & 1730 & - & 1080 & 540 \\
{$[\mathrm{VO}($ ambmadh $)] \mathrm{SO}_{4}$} & 3380 & 1610 & 1736 & 950 & 1100 & 510 \\
\hline
\end{tabular}

\section{Electronic Spectra}

The UV-visible spectrum of the Schiff base ligand and its complexes were recorded in DMSO solution in the range of 200 to $800 \mathrm{~nm}$ regions and the data are presented in Table 3 .

Table 3. Absorption Spectral data (nm) of the ligand and its Complexes

\begin{tabular}{cccc}
\hline & \multicolumn{3}{c}{ Absorption $\left(\lambda_{\max }\right)$} \\
\cline { 2 - 4 } Compound & $\mathrm{d}-\mathrm{d}$ & $\begin{array}{c}\pi \rightarrow \pi^{*} \\
\text { Benzene/ imino }\end{array}$ & $\begin{array}{c}\mathrm{n} \rightarrow \pi^{*} \\
\text { Azomethine }\end{array}$ \\
\hline Ligand (ambmadh) & - & 260 & 370 \\
{$[\mathrm{Cu}($ ambmadh $)]\left(\mathrm{ClO}_{4}\right)_{2}$} & 580 & 265 & 320,430 \\
{$[\mathrm{Ni}(\mathrm{ambmadh})]\left(\mathrm{ClO}_{4}\right)_{2}$} & 535 & 250 & 320,390 \\
{$[\mathrm{Zn}($ ambmadh $)] \mathrm{SO}_{4}$} & 480 & 240,270 & 320,440 \\
{$[\mathrm{VO}(\mathrm{ambmadh})] \mathrm{SO}_{4}$} & 550 & 240 & 310,410 \\
\hline
\end{tabular}

The absorption spectrum of free ligand consist of an intense bands centered at $360 \mathrm{~nm}$ attributed to $n \rightarrow \pi^{*}$ transitions of the azomethine group. Another intense band in higher energy region of the spectra of the free ligand was related to $\pi \rightarrow \pi^{*}$ transitions of benzene rings ${ }^{16}$. These transitions are found also in the spectra of the complexes, but they shifted towards lower frequencies, confirming the coordination of the ligand to the metallic ions ${ }^{17}$. Further, the d-d transition of the complexes showed a broad band centered at 550-650 nm suggesting an approximate square planar geometry of the ligand around the metal $\operatorname{ion}^{18}$. This is due to electron delocalisation over whole molecule on complexation. Based on these data, a square planar geometry has been assigned to the complexes except VO(IV) complex which has square-pyramidal geometry. These values are comparable with other reported complexes ${ }^{19,20}$.

\section{Cyclic voltammetry}

\section{Copper}

The cyclic voltammogram of the Cu complex in DMSO scan rate $100 \mathrm{mVs}^{-1}$ shows a welldefined redox process corresponding to the formation of $\mathrm{Cu}(\mathrm{II}) / \mathrm{Cu}(\mathrm{I})$ couple at $\mathrm{Ep}_{\mathrm{a}}=0.53 \mathrm{~V}$ and $\mathrm{Ep}_{\mathrm{c}}=0.24 \mathrm{~V}$. This couple is found to be quasi-reversible with $\Delta \mathrm{E}_{\mathrm{p}}=0.289 \mathrm{~V}$ and the ratio of anodic to cathodic peak currents corresponding to a simple one-electron process ${ }^{21}$.

\section{Vanadium}

The cyclic voltammogram of the vanadyl complex shows one electron transfer redox peak corresponding to the formation of the $\mathrm{VO}(\mathrm{IV}) / \mathrm{VO}(\mathrm{V})$ and $\mathrm{VO}(\mathrm{IV}) / \mathrm{VO}$ (III) couples ${ }^{22}$. The two peaks are different which indicate the involvement of two electro active species in solution corresponding to $\mathrm{VO}(\mathrm{V})$ and $\mathrm{VO}(\mathrm{III})^{23}$. 


\section{Nickel}

The nickel complex shows two peaks were obtained which are due to $\mathrm{Ni}(\mathrm{II})-\mathrm{Ni}(\mathrm{I})$ and $\mathrm{Ni}(\mathrm{I})$ $\mathrm{Ni}(\mathrm{II})$. For cathodic process of the $\mathrm{Ni}(\mathrm{II})-\mathrm{Ni}(\mathrm{I})$, the observed peak potential are strongly depends on donor strength of the ligand. The peak separation between the related cathodic and anodic waves indicate a quasi-reversible and reversible redox reactions for $\mathrm{Ni}(\mathrm{II}) / \mathrm{Ni}(\mathrm{I})$ and $\mathrm{Ni}(\mathrm{I}) / \mathrm{Ni}(\mathrm{II})$ systems respectively ${ }^{24}$.

Zinc

The zinc complexes, the one oxidation and one reduction peak were obtained. This is due to ligand nature. $\mathrm{Zn}(\mathrm{II})$ ion does not undergo reduction or_oxidation in the given potential range because of invariable oxidation state of $\mathrm{Zn}$ is +2 .

\section{Biological activity}

The free ligand and its metal complexes were tested against the bacterial species Staphylococcus Aureus, Bacillus subtilis, Pseudomonas aeruginosa, and Escherichia coli. Chloramphenicol as a standard antibacterial agent or reference was evaluated for their antibacterial activity and the result was compared with the free ligand and its metal complexes. The comparison of the biological activities of the synthesized compounds and some known antibiotic shows the following results:

1. The free ligand and its metal complexes show positive effect towards Staphylococcus aureus more than standard.

2. The free ligand and $\mathrm{Ni}(\mathrm{II})$ complex show higher antibacterial effect than that of standard.

3. The copper(II), zinc(II) and oxovanadium(IV) complexes have more biological activity than ligand, Nickel and standard. Such increased activity of the metal chelates can be explained based on chelation theory ${ }^{25}$. On chelation, the polarity of the metal ion will be reduced to a greater extent due to the overlap of the ligand orbital and partial sharing of the positive charge of the metal ion with donor groups ${ }^{26,27}$. Further, it increases the delocalization of $\pi$ electrons over the whole chelate ring and enhances the penetration of the complexes into lipid membranes and blocking of the metal binding sites in the enzymes of microorganisms ${ }^{28}$. These complexes also disturb the respiration process of the cell and thus block the synthesis of proteins, which restricts further growth of the $\operatorname{organisms}^{29}$.

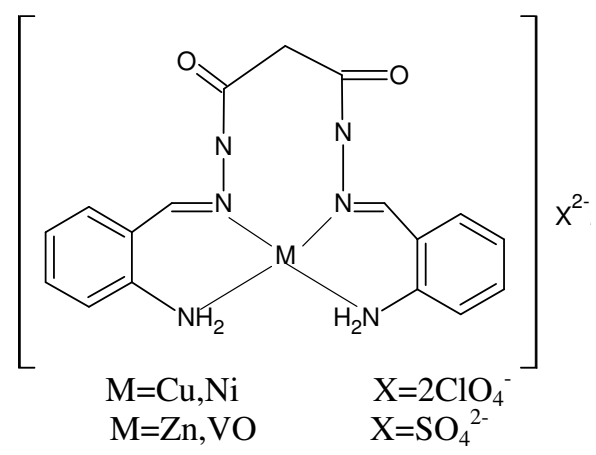




\section{Conclusion}

The spectral data show that the Schiff base exist as tetradentate ligand by bonding to the metal ion through the phenolic nitrogen and azomethine nitrogen. The analytical data show the presence of one metal ion per ligand molecule and suggest a mononuclear structure for the complexes. The electronic spectral data is in the favour of square planer geometry for $\mathrm{Cu}(\mathrm{II}), \mathrm{Ni}(\mathrm{II})$ and tetrahedral geometry for $\mathrm{Zn}(\mathrm{II})$ complexe, Square pyramidal structure for VO(IV) complexe. On the basis of chelation theory, metal complexes have more biological activity than free ligands.

\section{References}

1. Henri L K W, Tagenine J and Minugupta_B, Ind J. Chem., 2001, 40A, 999.

2. Rajavel R and Krishnan C N, Orient. J. Chem., 1998, 14(2), 313.

3. Erdal Canpolat and Mehmet Kaya, J. Coord. Chem, 2004, 57(14), 1217- 1223.

4. Jian-ning LIV. Bo-wanWU, Bing Zhang and Yongchun LIU, Turk. J. Chem., 2006, 30, 41-48.

5. (a) Nair R, Shah A, Baluja S and Chanda, J. Serbi, Chem. Soc., 2006, 71(7), 733-744.

(b) Lal R A, Baluswamy D and Kumar A, Ind. J. Chem, 2006, 45A, 619.

6. Morad Ajaily M M E and Ben Gweirif S, Journal of Science and its Application. 2007, 1, 72.

7. Appeal A.M., Newel R. and Dubois M.R., Inorg. Chem., 2005, 44, 3046

9. Temel H. J. Coord. Chem., 2004, 57(9),723.

10. Ghames A, Doudi T, Allain M and Bouet G M, Polyhedron, 2005, 25, 3201- 3208.

11. Iskander M R, Ei-Syed L and Ismail K Z, Trans. Met. Chem., 1979, 4, 225.

12. Thankamony M and Mohanan.K, Ind J. Chem, 2007, 46A, 249.

13. Thomas M, Nair M K M and Radhakrishan R K, Synth. React Inorg. Met Org. Chem. 1995, 25, 471.

14. Nakamoto K, Infrared and Raman Spectra of inorganic and coordination Compounds (New York: Wiley), 1997, $3^{\text {rd }}$ Ed.,.

15. Xiu R B, Mintz F L, You X Z, Wang R X, Yue Q, Meng Q J, Lu Y J and D V, Derveer, Polyhedron, 1996, 15, 4585.

16. Conpolat E and Kaya M, J. Coord. Chem., 2004, 57(14), 1217 - 1223.

17. Friedel R A and Orchin M, Ultraviolet Spectra of Aromatic Compounds Chemistry. John Wiley, New york, 1958.

18 Feigl F, Chemistry of Specific, Selective and Sensitive Reactions, Academic Press, 1949

19. Lever A B P, Inorganic electronic spectroscopy (New York: Elsevier), 1968, $2^{\text {nd }}$ Ed.

20. Warad D U, Satish C D, Kulkarini V H and Bjgur C S. Ind J. Chem. 2000, 39A, 415.

21. Losada J, Del Peso I and Beyer L, Inorg. Chim. Acta, 2001, 32, 107.

22. Knopp P, Weighardt K, Nuber B, Weiss J and Sheldrick W S, Inorg. Chem., 1990, 29, 363.

23. Matsubayashi G, Akiba K and Tanaka T, Inorg. Chem., 1988, 27, 4744.

24. Bard A J and Izatt L R, Electrochemical Methods: Fundamentals and Applications: $2^{\text {nd }}$ Ed., Wiley: New York, 2001.

25. Tweedy B G, Phyto Pathology., 1964, 55, 910.

26. Kralova K, Kissova K, Svajlenova O and Vanco J, Chem. Pap., 2004, 58(5), 361.

27. Parekh J, Inamdhar P, Nair R, Baluja S and Chanda S, J. Serb.Chem., Soc., 2005, 70, 1161.

28. Vaghasia Y, Nair R, Soni M, Baluja S and Chanda S, J. Serb. Chem. Soc. 2004, 69, 991.

29. Raman N, Res. J. Chem. Environ., 2005, 9(4) 


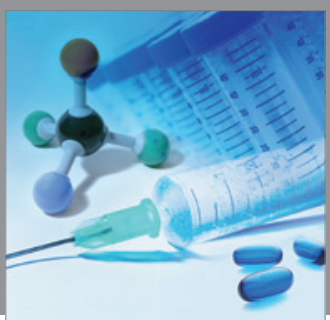

International Journal of

Medicinal Chemistry

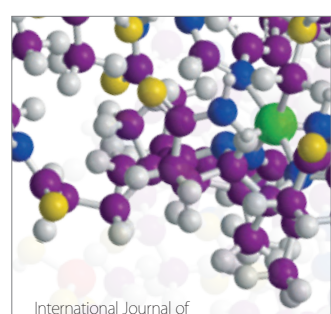

Carbohydrate Chemistry

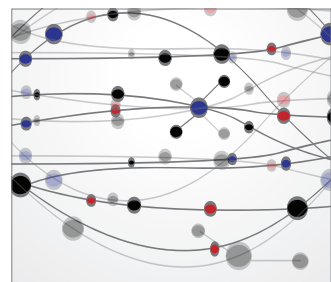

The Scientific World Journal
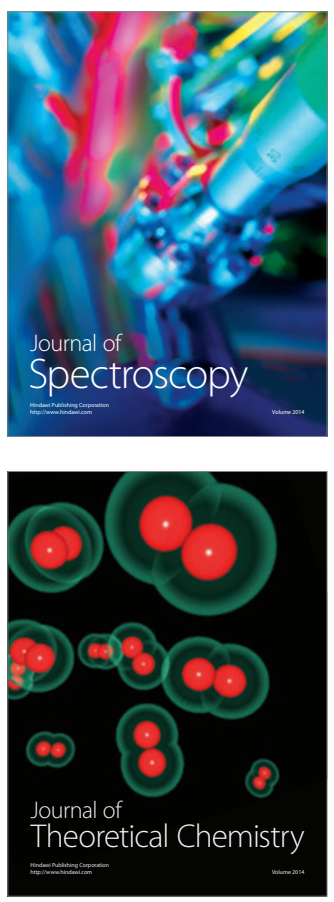
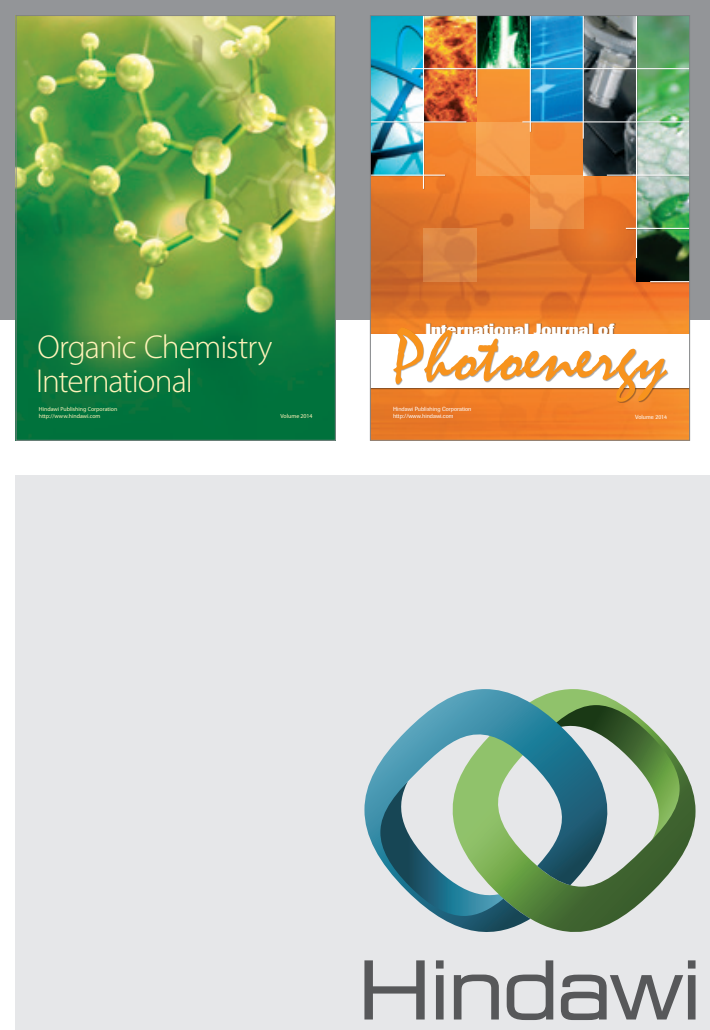

Submit your manuscripts at

http://www.hindawi.com
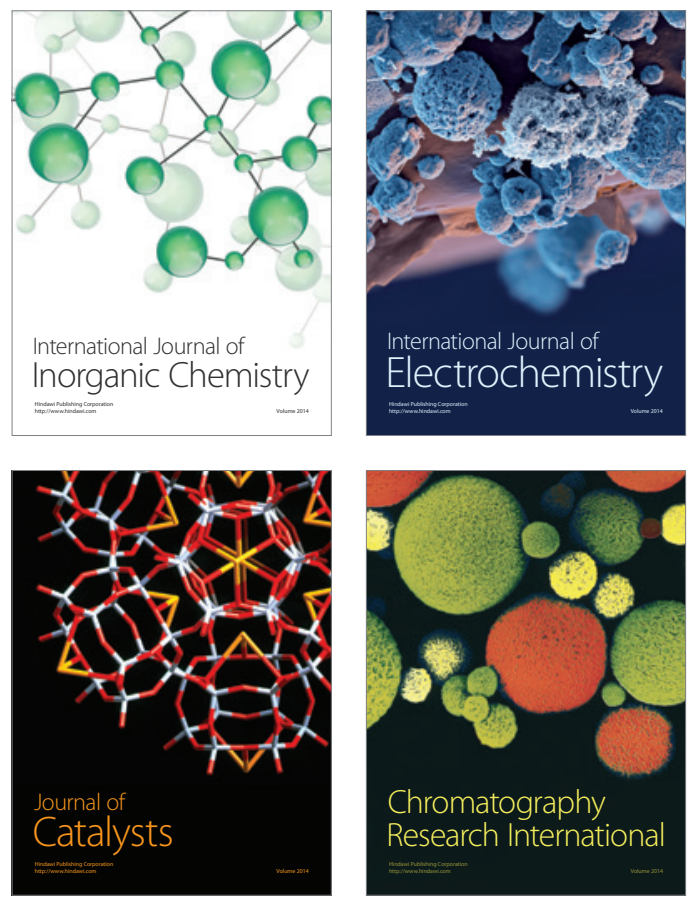
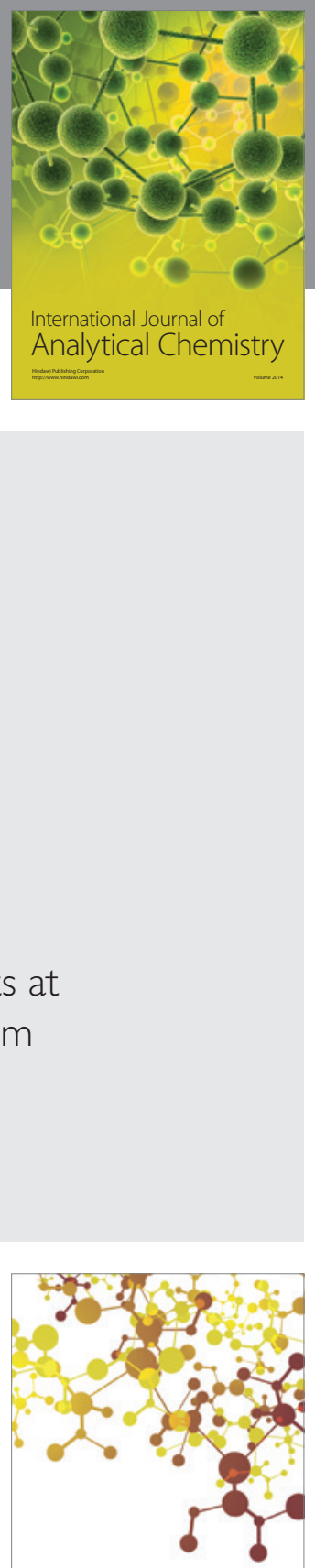

Journal of

Applied Chemistry
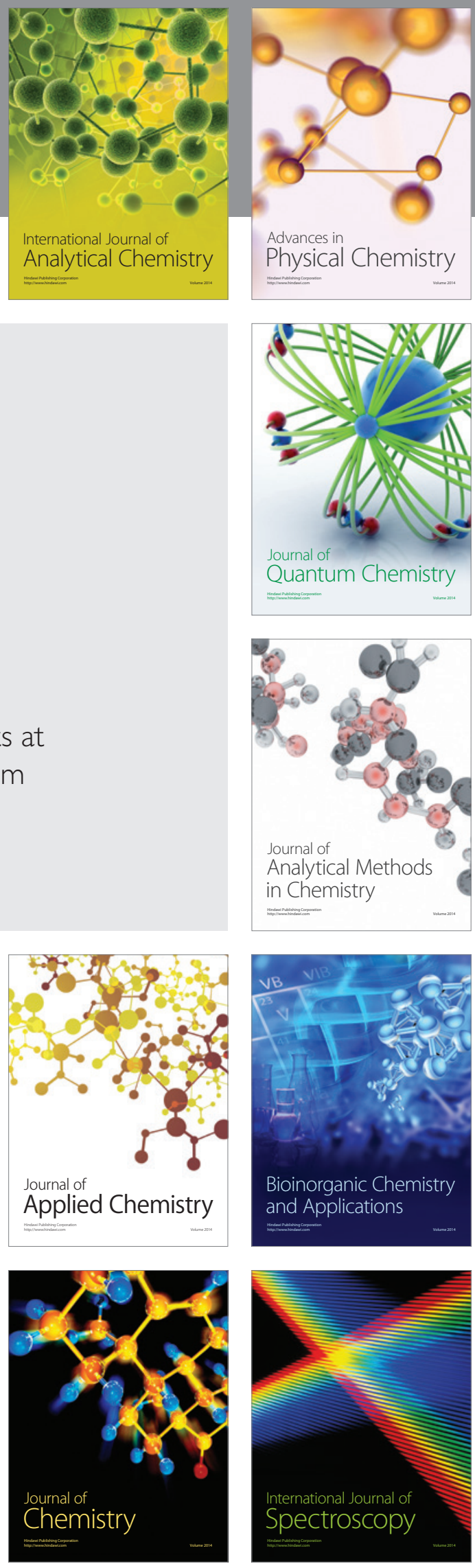